Wiraraja Medika: Jurnal Kesehatan
https://www.ejournalwiraraja.com/index.php/FIK
2088-415x (Print) |2685-9998 (online)

\title{
Gambaran Pelaksanaan Social Distancing Dan Protokol Kesehatan Dimasa Pandemi Covid-19 Pada Mahasiswa
}

\author{
Supriyadi ${ }^{1}$, Vita Maryah Ardiyani ${ }^{2}$, Novita Dewi ${ }^{3}$ \\ ${ }^{1,2,3}$ Fakultas Ilmu Kesehatan Universitas Tribhuwana Tunggadewi \\ ners9supriyadi@gmail.com** \\ *Corresponding author
}

\begin{tabular}{l}
\hline Informasi artikel \\
\hline Sejarah artikel: \\
Received: 04-02-2021 \\
Revised: $31-05-2021$ \\
Accepted: 20-06-2021 \\
\hline Kata kunci: \\
COVID-19 \\
Social distancing \\
Protokol kesehatan
\end{tabular}
\begin{abstract}
ABSTRAK
Corona Virus Disease 2019 (COVID-19) merupakan penyakit saluran pernafasan yang menjadi wabah diseluruh dunia saat ini. Tindakan pencegahan yang murah dan mudah untuk membantu menekan penularan dan penyebaran COVID-19 antaralain; social distancing, memakai masker mencuci tangan dan menjaga jarak. Penelitian ini bertujuan untuk mengidentifikasi pelaksanaan social distancing dan protokol kesehatan dimasa pandemi COVID-19 pada mahasiswa. Desain penelitian menggunakan deskriptif. Populasi dalam penelitian adalah seluruh mahasiswa dengan jumlah sampel sebanyak 222 mahasiswa, yang diambil secara simple random sampling. Variabel bebas penelitian terdiri dari; social distancing, memakai masker, mencuci tangan, menjaga jarak. Instrumen penelitian menggunakan lembar kuesioner pelaksanaan social distancing dan protokol kesehatan pada mahasiswa, kuesioner diberikan secara online. Data dianalisis secara deskriptif. Hasil penelitian menunjukkan bahwa sebagian besar responden melaksanakan social distancing yaitu sebanyak 64.9\%, hampir seluruh responden selalu memakai masker sebanyak (95\%), sebagian besar responden selalu mencuci tangan sebanyak (58.1\%), dan sebagian besar responden selalu menjaga jarak sebanyak (64.9\%). Perlu dilaksanakan penelitian lebih lanjut dan mengobservasi pelaksanaan social distancing dan protokol kesehatan terhadap kejadian positif COVID-19 pada mahasiswa dilingkungan pendidikan Indonesia.

ABSTRACT

Corona Virus Disease 2019 (COVID-19) is a respiratory disease that is becoming a worldwide epidemic during this time. Cheap and easy preventive measures to help reduce the transmission and spread of COVID-19, are including; social distancing, wearing mask, washing hands, and physical distancing. The research aim was to identify the implementation of social distancing and health protocols during the pandemic of COVID-19 among the student. The descriptive design was used to the 222 students which were selected by a simple random sampling technique. The independent variables are including social and physical distancing, wearing proper masks, and washing hands regularly. Online-based questionnaires of social distancing implementation and health protocol handed over to the participant. Data were analyzed using a sort of descriptive set. The results showed most of the participants practice the social distancing and physical distancing (64.9\%), wearing proper masks (95\%), and washing their hands regularly (58.1\%). Further observation to the implementation of social distancing and health protocols of COVID-19 incident in the Indonesian education environment is demanding to avoid highly positive confirmed case among the university students.
\end{abstract}

Key word:

COVID-19

Social distancing

Health protocol

\section{PENDAHULUAN}

COVID-19 merupakan penyakit yang disebabkan oleh virus SARS-Cov-2 varian baru. SARS-CoV-2 merupakan istilah dari sindrom pernafasan akut coronavirus 2, yang pertama kali ditemukan di Wuhan China dan kemudian menyebar di hampir seluruh Negara di dunia. SARS-CoV-2 tergolong virus yang unik yaitu dari subgenus sarbecovirus dari subfamily 
Orthocoronavirinae, yang diidentifikasi sebagai pathogen penyakit 2019 atau Coronavirus Disease 2019 (COVID-19) pada Januari 2020 (Chaomin WU, 2020). COVID19 merupakan penyakit yang menyebabkan infeksi saluran pernafasan, dimana penyebarannya antar manusia sangat cepat. Belakangan ini dapat diketahui bahwa banyak penduduk diberbagai Negara di dunia yang sudah terinfeksi oleh COVID-19 ini, sehingga WHO menyatakan darurat kesehatan global (Wu, et al., 2020; West, Michie, Rubin, \& Amlôt, 2020; Roy, et al., 2020; Fahey \& Hino, 2020)

$\begin{array}{cc}\text { Menurut data } & \text { World Health } \\ \text { Organization } & \text { (WHO) Coronavirus }\end{array}$
Disease(COVID-19) Dashboard yang memaparkan bahwa per tanggal 20 Januari 2021 jumlah total orang yang terkonfirmasi positif COVID-19 di seluruh dunia sebanyak 94.963.847 jiwa, sedangkan jumlah total kasus terkonfirmasi COVID-19 di Indonesia yaitu sebanyak 927.380 jiwa (WHO, 2021).Jumlah kasus terkonfirmasi COVID19 di Jawa Timur per tanggal 20 Januari 2021 sebanyak 102.152 jiwa, dan jumlah terkonfirmasi kasus COVID-19 di kota Malang sebanyak 4.799 jiwa (JATIMPROV, 2021).

COVID-19 merupakan penyakit yang dapat ditularkan secara asimtomatik, presimtomatik dan dengan gejala. Penyakit ini dapat secara luas dan cepat menyebar karena penularannya malalui droplet inhalation antar manusia dengan jarak dekat dan kontak erat, droplet yang dikeluarkan oleh orang yang terinfeksi COVID-19 pada saat batuk atau bersin mengandung virus, kemudian droplet akan terbawa oleh angin dan terhirup oleh seseorang yang berada dekat dengan orang yang terinfeksi, atau virus yang keluar bersama droplet akan menempel pada permukaan sebuah benda kemungkinan dapat menempel pada tangan seseorang jika tangan menyentuh bendatersebut (Wiersinga, Rhodes, Cheng, Peacock, \& Prescott, 2020). Menurut World Health Organization (2020) gejala yang ditimbulkan oleh COVID-19 diantaranya; gejala pernafasan ringan, gejala akut/berat, sepsis dengan disfungsi organ hingga kematian. Gejala yang paling umum ditimbulkan antaralain: demam, batuk kering, sesak nafas, gangguan perasa dan penciuman (anosmia), kelelahan, nyeri otot, sakit kepala, serta gangguan saluran pencernaan seperti: mual, muntah, dan diare. Waktu rerata antara paparan virus sampai timbulnya gejala yaitu 5-11 hari(Mortenson, Malani, \& Ernst, 2020).

Tindakan preventif yang dapat dilakukan untuk mencegah penyebaran COVID-19 yaitu protokol kesehatan, dengan menerapkan beberapa tindakan diantaranya memakai masker, mencuci tangan dan menjaga jarak ketika bersosialisasi baik didalam lingkungan pendidikan maupun ketika berada di luar lingkungan pendidikan (Melnick \& Darling-Hammond, 2020). Menurut Yen, Schwartz, Chen, King, Yang, \& Hsueh, (2020) menyebutkan bahwa untuk membatasi penularan COVID-19 diperlukan adaptasi baru yang menggabungkan perilaku antara lain isolasi, pemakaian masker dan penggunaan disinfektan pada tangan. Perilaku tersebut dapat mencegah siklus penularan dari komunitas-rumah sakit-komunitas luas. Berdasarkan paparan diatas maka perlu adanya gambaran mengenai pelaksanaan social distancing dan protokol kesehatan dimasa pandemi COVID-19 pada mahasiswa .

\section{METODE PENELITIAN}

Penelitian ini dilaksanakan pada tanggal 15 Juli 2020. Metode yang digunakan dalam penelitian ini yaitu deskriptif dengan menjabarkan pelaksanaan social distancing dan protokol kesehatan diantaranya memakai masker, mencuci tangan dan menjaga jarak. Populasi dalam penelitian adalah seluruh mahasiswa aktif salah satu Universitas swasta di Malang, yang sedang melaksanakan pendidikan secara daring, dengan jumlah sampel sebanyak 222 mahasiswa, diambil secara simple random sampling. Peneliti memberikan penjelasan sebelum penelitian berlangsung dan responden diminta untuk mengisi lembar persetujuan penelitian. Instrumen penelitian menggunakan lembar kuesioner pelaksanaan social distancing dan protokol kesehatan pada mahasiswa, kuesioner diberikan secara online. Kuesioner terdiri dari 4 pertanyaan antaralain; pelaksanaan social distancing dengan jawaban Ya/Tidak; penggunaan masker; mencuci tangan dengan tekhnik 6 langkah, dan menjaga jarak dengan jawaban selalu/jarang/tidak pernah. Kuesioner tersebut digunakan untuk mengukur perilaku keseharian mahasiswa. Selanjutnya data dianalisis secara deskriptif dan disajikan dalam bentuk tabel distribusi frekuensi. 


\section{HASIL DAN PEMBAHASAN}

Berikut karakteristik responden yang meliputi pelaksanaan social distancing dan protokol kesehatan yang terdiri dari memakai masker, mencuci tangan dan menjaga jarak.

Tabel 1 Distribusi frekuensi berdasarkan Pelaksanaan Social distancing dan Protokol Kesehatan Dimasa Pandemi COVID-19 Pada Mahasiswa

\begin{tabular}{ccc}
\hline $\begin{array}{c}\text { Pelaksanaan Social } \\
\text { distancing }\end{array}$ & $\mathbf{f}$ & $\mathbf{\%}$ \\
\hline Ya & 144 & 64.9 \\
Tidak pernah & 78 & 35.1 \\
\hline Pelaksanaan & & \\
Protokol Kesehatan & & \\
\hline Memakai Masker & & \\
Selalu & 211 & 95 \\
Jarang & 10 & 4.5 \\
Tidak pernah & 1 & 0.5 \\
\hline Mencuci Tangan & 129 & \\
Selalu & 58.1 \\
Jarang & 85 & 38.3 \\
Tidak pernah & 8 & 3.6 \\
\hline Menjaga Jarak & & \\
Selalu & 144 & 64.9 \\
Jarang & 70 & 31.5 \\
Tidak pernah & 8 & 3.6 \\
\hline Total & $\mathbf{2 2 2}$ & $\mathbf{1 0 0}$ \\
\hline
\end{tabular}

Berdasarkan Tabel 1 didapatkan hasil bahwa sebagian besar responden melaksanakan social distancing yaitu sebanyak $64.9 \%$, hampir seluruh responden selalu memakai masker sebanyak (95\%), sebagian besar responden selalu mencuci tangan sebanyak (58.1\%), dan sebagian besar responden selalu menjaga jarak sebanyak (64.9\%).

\section{PEMBAHASAN}

Sebagian besar responden dalam penelitian melaksanakan social distancing dan menjaga jarak. Tindakan isolasi dan social distancing merupakan langkah efektif yang dapat mengendalikan penyebaran COVID-19, tindakan tersebut bertujuan untuk melindungi diri sendiri dan orang lain sehingga tidak menularkan dan tertular oleh virus. Selain itu menjaga jarak fisik antar individu juga dapat meminimalkan risiko penularan secara langsung melalui droplet, jarak fisik yang disarankan adalah sekitar $2 \mathrm{~m}$, tetapi disarankan lebih dari itu karena droplet yang berupa aerosol dapat bergerak lebih jauh(West, Michie, Rubin, \& Amlôt, 2020).
Menurut Courtemanche, Garuccio, Le, Pinkston, \& Yelowitz, (2020) menyatakan bahwa social distancing dianggap mampu mencegah dan menahan penyebaran COVID-19, social distancing yang diterapkan oleh berbagai Negara bagian USA diantaranya adalah melarang pelaksanaan acara besar, penutupan sekolah, tempat hiburan, gym, bar, dan restoran. Social distancing yang diterapkan disinyalir dapat menurunkan penyebaran virus sebesar 5,4\% setiap harinya. Social distancing bertujuan untuk mengurangi dan membatasi interaksi sosial seseorang, sehingga dapat menyelamatkan jutaan nyawa selama pandemi COVID-19 (Lunn, Timmons, Belton, Barjaková, Julienne, \& Lavin, 2020).

Hasil penelitian yang dilakukan oleh Cowling, et al., (2020) menunjukkan bahwa intervensi non-farmakologis diantaranya seperti, social distancing, isolasi mandiri, dan menjaga jarak sosial dapat membantu mengurangi penularan COVID-19 di Hong Kong. Menjaga jarak fisik antara satu orang dengan orang yang lain merupakan salah satu upaya yang bisa dilakukan untuk membantu mencegah penularan COVID-19, namun penerapan dalam menjaga jarak fisik tidak sepenuhnya mampu mencegah penularan virus jika tidak dibarengi dengan social distancing, pemakaian alat pelindung diri minimal seperti pemakaian masker medis, dan kebersihan tangan dalam hal ini adalah cuci tangan menggunakan sabun/disinfektan (Jones, Qureshi, Temple, Larwood, Greenhalgh, \& Bourouiba, 2020).

Hampir seluruh responden memakai masker. Penggunaan masker merupakan bagian dari paket komprehensif tindakan pencegahan dan pengendalian penyebaran COVID-19. Beberapa jenis masker yang direkomendasikan ialah masker medis dan non-medis (Supinganto et al, 2021). Masker medis mempunyai daya saring droplet yang tinggi mencapai 95\%, karena masker medis mempunyai sekitar 3 sampai 4 lapis, dan setiap lapisnya mempunyai serat yang sangat halus. Masker non-medis biasanya mempunyai daya saring droplet sekitar 70\%, masker ini terbuat dari kombinasi kain yang berbeda pada lapisannya dan tersedia dalam berbagai bentuk. Bahan masker yang bervariasi menyebabkan daya saring masker juga berbeda (World Health Organization, 2020). 
Penggunaan masker dapat melindungi diri sendiri dan orang lain. Masker mampu mencegah keluar dan masuknya droplet yang dikeluarkan bersamaan pada saat orang mengalami bersin atau batuk. Masker sebaiknya digunakan untuk orang sehat maupun orang yang terinfeksi (Feng, Marchal, Sperry, \& Yi, 2020). Hasil penelitian yang dilakukan oleh Cheng, et al., (2020) yang meyimpulkan bahwa pemakaian masker oleh masyarakat luas dapat berkontribusi dalam mengendalikan COVID-19 dengan mengurangi jumlah droplet yang dikeluarkan melalui batuk maupun bersin.

Sebagian besar responden penelitian selalu mencuci tangan. Kebersihan tangan dianggap sebagai tindakan yang sangat penting dalam mengendalikan infeksi. Tindakan mencuci tangan yang tepat dapat memutus siklus transmisi dan mengurangi risiko penularan COVID-19 antara 6\% sampai 44\%, mencuci tangan merupakan cara yang dianggap paling murah dan mudah untuk melindungi setiap individu dari risiko tertular penyakit (Chen, Ran, Liu, $\mathrm{Hu}, \mathrm{Du}$, \& Tan, 2020). Langkah yang bisa dilakukan untuk meminimalisir kemungkinan tertular virus COVID-19 diantaranya adalah memakai masker dan mencuci tangan dengan benar memakai sabun atau hand sanitizer. (Kennedy, Zambrano, Wang, \& Neto, 2020). Pencegahan penularan COVID-19 yang bisa dilakukan yaitu dengan cara mencuci tangan sesering mungkin dengan tekhnik yang baik dan benar dengan sabun dan air atau menggunakan desinfektan berbasis alcohol seperti yang telah direkomendasikan oleh WHO (Pradhan, Biswasroy, Naik, Ghosh, \& Rath, 2020).

Menurut Elengoe, (2020) dalam artikelnya menyebutkan bahwa tindakan pencegahan penularan COVID-19 yang bisa dilakukan dan diterapkan berdasarkan WHO, Tindakan pencegahannya antara lain; mencuci tangan secara teratur dengan sabun atau larutan desinfektan, menghindari berjabat tangan, selalu memakai masker, memakai sarung tangan, menjaga jarak sosial minimal 1-2 m, mematuhi etika batuk yang benar, isolasi mandiri dan menghindari keramaian serta tidak bepergian ke daerah yang terkena dampak COVID-19. Tindakan tersebut dapat membantu menekan penyebaran infeksi virus, jika dilakukan secara ketat oleh setiap individu (Suprayitno et al, 2020)

\section{Kesimpulan}

Sebagian melaksanakan social distancing dan responden yang melaksanakan protokol kesehatan antaralain hampir seluruh responden selalu memakai masker, serta sebagian besar selalu mencuci tangan dan menjaga jarak.

\section{Saran}

Perlu dilaksanakan penelitian lebih lanjut dan mengobservasi pelaksanaan social distancing dan protokol kesehatan terhadap kejadian positif COVID-19 pada mahasiswa dilingkungan pendidikan Indonesia.

\section{Referensi}

Chen, X., Ran, L., Liu, Q., Hu, Q., Du, X., \& Tan, X. (2020). Hand Hygiene, MaskWearing Behaviors and Its Associated Factors during the COVID-19 Epidemic: A CrossSectional Study among Primary School Students in Wuhan, China. Environmental Research and Public Health, 1-11.

Cheng, V. C.-C., Wong, S.-C., Chuang, V.-M., So , S.-C., Chen, J.-K., Sridhar, S., et al. (2020). The role of community-wide wearing of face mask for control of coronavirus disease 2019 (COVID19) epidemic due to SARS-CoV-2. Journal of Infection, 107-114.

Courtemanche, C., Garuccio, J., Le, A., Pinkston, J., \& Yelowitz, A. (2020). Strong Social Distancing Measures In The United States Reduced The COVID-19 Growth Rate. HEALTH AFFAIRS , 1-8.

Cowling, B., Ali, S., Tiffany W Y Ng, Tsang, T., Li, J., Fong, M., et al. (2020). Impact assessment of nonpharmaceutical interventions against coronavirus disease 2019 and influenza in Hong Kong: an observational study. Lancet Public Health, e279-288.

Elengoe, A. (2020). COVID-19 Outbreak in Malaysia. Osong Public Health Res Perspect, 93-100.

Fahey, R., \& Hino, A. (2020). COVID-19, digital privacy, and the social limits on data-focused public health responses. International Journal of Information Management, 1-5.

Feng, Y., Marchal, T., Sperry, T., \& Yi, H. (2020). Influence of wind and 
relative humidity on the social distancing effectiveness to prevent COVID-19 airborne transmission: A numerical study. Journal of Aerosol Science, 1-19.

JATIMPROV. (2021, January 21). Retrieved January 21, 2021, from JATIM TANGGAP COVID-19: http://infocovid19.jatimprov.go.id/

Jones, N., Qureshi, Z., Temple, R., Larwood, J., Greenhalgh, T., \& Bourouiba, L. (2020). Two metres or one: what is the evidence for physical distancing in covid-19? BJM, 1-6.

Kennedy, D., Zambrano, G., Wang, Y., \& Neto, O. (2020). Modeling the effects of intervention strategies on COVID-19 transmission dynamics. Journal of Clinical Virology, 1-7.

Lunn, P. D., Timmons, S., Belton, C. A., Barjaková, M., Julienne, H., \& Lavin, C. (2020). Motivating social distancing during the COVID-19 pandemic: An online experiment. Social Science \& Medicine, Vol.265.

Melnick, H., \& Darling-Hammond, L. (2020). Reopening Schools in the Context of COVID-19: Health and Safety Guidelines From Other Countries. LEARNING POLICY INSTITUTE, 1-13.

Mortenson, L., Malani, P., \& Ernst, R. (2020). Caring for Someone With COVID-19: Care of individuals with COVID-19 is 2-fold: support the patient and prevent yourself and others from contracting SARS-CoV-2. JAMA, 1016.

Pradhan, D., Biswasroy, P., Naik, P., Ghosh, G., \& Rath, G. (2020). A Review of Current Interventions for COVID-19 Prevention. Archives of Medical Research, 363-374.

Roy, D., Tripathy, S., Kar, S. K., Sharma, N., Verma, S. K., Sharma, N., et al. (2020). Study of knowledge, attitude, anxiety \& perceived mental healthcare need in Indian population during COVID-19 pandemic. Asian Journal of Psychiatry, 1-7.

Supinganto, A., Pramana, C., Sirait, L. I., Kumalasari, M. L. F., Hadi, M. I., Ernawati, K., Staryo, N. A., Suprayitno, E., Utami, K., \& Hadi, S. P. I. (2021). The Use of Masks, as an Effective Method in Preventing the Transmission of the COVID-19, During Pandemic and the New
Normal Era: A Review. (February 7, 2021).

Suprayitno, E., Rahmawati, S., Ragayasa, A., \& Pratama, M. Y. (2020). Pengetahuan dan Sikap Masyarakat dalam Pencegahan COVID-19. Journal Of Health Science (Jurnal Ilmu Kesehatan), 5(2), 68-73.

West, R., Michie, S., Rubin, G., \& Amlôt, R. (2020). Applying principles of behaviour change to reduce SARSCoV-2 transmission. NATuRe HUMAN BeHAVIOUR, 451-457.

WHO. (2021, January 21). WHO Coronavirus Disease (COVID-19) Dashboard. Retrieved January 21, 2021, from https://covid19.who.int/

Wiersinga, W., Rhodes, A., Cheng, A., Peacock, S., \& Prescott, H. (2020). Pathophysiology, Transmission, Diagnosis, and Treatment of Coronavirus Disease 2019 (COVID19) A Review . JAMA , 782-793.

World Health Organization. (2020, June 05). Advice on the use of masks in the context of COVID-19. Interim guidance, 1-16.

Wu, C., Chen, X., Cai, Y., Xia, J., Zhou, X., Xu, S., et al. (2020). Risk Factors Associated With Acute Respiratory Distress Syndromes and Death in Patients With Coronavirus Disease 2019 Pneumonia in Wuhan, China. JAMA Internal Medicine, 934-943.

Yen , M.-Y., Schwartz , J., Chen, S.-Y., King, C.-C., Yang, G.-Y., \& Hsueh, P.-R. (2020). Interrupting COVID-19 transmission by implementing enhanced traffic control bundling: Implications for global prevention and control efforts. Journal of Microbiology, Immunology and Infection, 377-380. 